\title{
Controlling factors of groundwater hydrochemistry in a small island's aquifer
}

\author{
${ }^{1,2 *}$ A. Z. Aris; ${ }^{2}$ M. H. Abdullah; ${ }^{2}$ A. Ahmed; ${ }^{3}$ K. K. Woong \\ ${ }^{1}$ Department of Environmental Sciences, Faculty of Environmental Studies, University Putra Malaysia, 43400 UPM \\ Serdang, Selangor, Malaysia \\ ${ }^{2}$ School of Science and Technology, University of Malaysia Sabah, 88999 Kota Kinabalu, Sabah, Malaysia \\ ${ }^{3}$ Department of Environmental Science and Engineering, Gwangju Institute of Science and Technology, Gwangju, \\ 500-712 South Korea \\ Received 25 April 2007; revised 24 July 2007; accepted 10 August 2007; available online 1 September 2007
}

\begin{abstract}
Factor analysis was applied to the hydrochemical data set of Manukan Island in order to extract the principal factors corresponding to the different sources of variation in the hydrochemistry. The application of varimax rotation was to ensure the clear definition of the main sources of variation in the hydrochemistry. The geochemical data of dissolved major, minor and trace constituents in the groundwater samples indicates the main processes responsible for the geochemistry evolution. By using Kaiser normalization, principal factors were extracted from the data for each location. The analysis reveals that there are four sources of solutes: (1) seawater intrusion; (2) leaching process of underlying rock mediated by $\mathrm{pH}$; (3) minerals weathering process and (4) dissolution of carbonate minerals characterized by high loadings of $\mathrm{Ca}, \mathrm{Zn}$ and $\mathrm{Mg}$. Such processes are dominated by the significant role of anthropogenic impact from the over abstraction of fresh water from the aquifer. Those factors contributed to the changes of the groundwater geochemistry behavior explain the effect of rising extraction of freshwater from the aquifer.
\end{abstract}

Key words: Factor analysis, groundwater, hydrochemistry, seawater intrusion, small island

\section{INTRODUCTION}

Groundwater of small island located in the tropical region, especially in Malaysia receives increasing stress such as contributed by anthropogenic factors. Over exploitation may cause the imbalance in the hydrological system. In such areas, groundwater is commonly the only water resources, and the most prevalent issue relevant is the quality of the groundwater. Groundwater quality deterioration could be due to seawater intrusion as a result of over exploitation. Since its existence has become the most important source of water supply for the small island's community, pumping from the upper phreatic zone is widely practiced. A case study was done on Manukan island. This island is under stress with the increasing number of tourist and human activities on the islands. Well known as diver's paradise, Manukan island received thousands of visitors a year and still increasing from year to year. While many atolls have been thoroughly 즐 Corresponding Author Email: zaharin@env.upm.edu.my Tel.: +603 8946 7461; Fax.: +603 89438019 studied (Abdullah, et al., 1997b; Abdullah and Musta, 1999; Abdullah, et al., 2004; Abdullah and Aris, 2005), the hydrochemistry of Manukan island has rarely been reported. Located about $7.45 \mathrm{~km}(4.02$ nautical miles) from Kota Kinabalu, Sabah, Manukan is one of the islands under Tunku Abdul Rahman Parks. This study was set to determine the controlling factor that significantly controls the chemistry of the groundwater in the island. All data were analyzed using factor analysis to investigate the principles of interaction of components and their integration into a system.

\section{MATERIALS AND METHODS}

Manukan island (5'57'-5 $58^{\prime} \mathrm{N}$ and $115^{\circ} 59^{\prime}-116^{\circ} 01^{\prime}$ E), (Fig. 1) has an area of $206000 \mathrm{~m}^{2}$. Almost $80 \%$ of the area is covered by forest in the high relief side, while the rest $20 \%$ of the area is developed for tourism activities which are located on the low lying area of the island. Manukan island is the park's second largest island of Tunku Abd Rahman Parks 
after Gaya island. It is surrounded by other small islands such as Sapi, Mamutik and Sulug. The island is a crescent shaped, one and half kilometer long and three of kilometer wide in the middle. Enacted under government's Parks Enactment 1978, the island is well known for its sandy beaches and corals, and being an attraction to visitors and divers. The management of the island is put under the supervision of The Sabah Parks Trustees. Geologically, Manukan island consists of interbedded sandstone and shale classified as the Crocker Formation deposited during Late Eocene to Middle Miocene (Basir, et al., 1991; Abdullah, et al., 1997a). An early study on the morphological of the island's aquifer conducted by Abdullah, et al. (1997a) found that the thickness of the overlying rocks are approximately, $11 \mathrm{~m}$ (at the southern area), $5.7 \mathrm{~m}$ (at the northern part) and $12 \mathrm{~m}$ (at the middle part) from the ground surface to the bedrock. Geologically, Manukan island is formed of carbonate rocks and overlain by Quarternary alluvium (Basir, et al., 1991). Reported by
Abdullah, et al. (1997a), the most abundant major element in both lowland and hill slope areas is $\mathrm{SiO}_{2}$. On the lowland, the sandstone has about the same thickness, with shale and carbonate coral deposits. The higher range of concentration of $\mathrm{CaO}$ in the lowland soils is mainly attributed to carbonate minerals. The alluviums are loose, not cemented and act as sufficient water storage which entirely depends on its thickness. The groundwater recharge for Manukan island aquifer depends entirely on the infiltration. Sabah has a warm and humid climate with annual rainfall range between 2000 - 2500 mm, humidity between 80 - $90 \%$ all year round and temperatures range from 21 to $32{ }^{\circ} \mathrm{C}$. The climate is affected by the northeast and southwest monsoons, tropical winds that alternate during the course of the year. The northeast monsoon blows from November to March, and the southwest monsoon from May to September and usually the periods between the monsoons are marked by heavy rainfall.

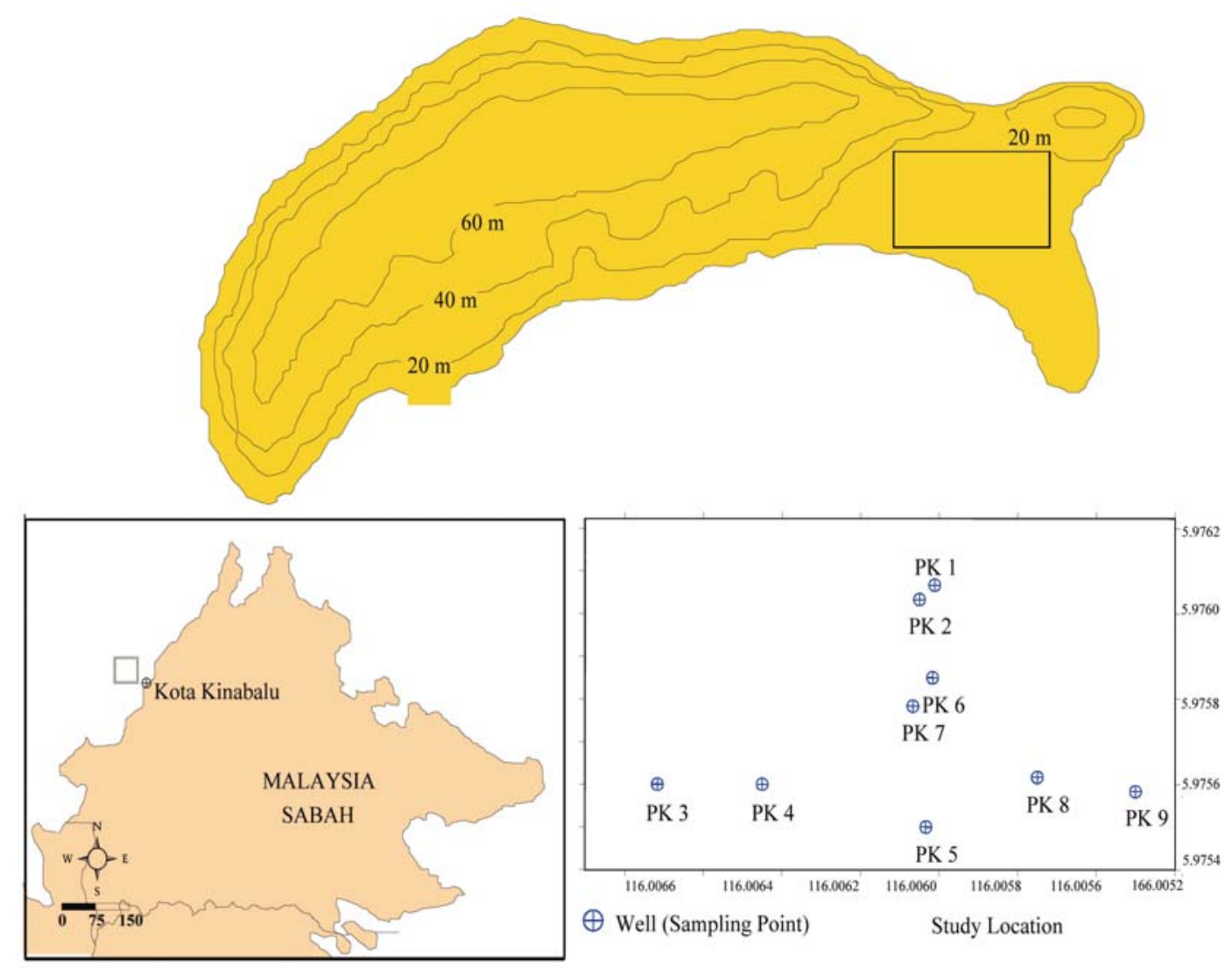

Fig. 1: Schematic map showing the geographical locality of Manukan island and sampling locations 
Sample collection and analysis

A total of 81 samples of groundwater in the study area were collected during March to July 2006 (8 March; 22 ${ }^{\text {nd }}$ May and 25 $5^{\text {th }}$ July 2006) from 9 production wells located on the low lying area of the island. Currently, there are nine production wells in the area (Fig. 1) used for extracting groundwater from its aquifer for the freshwater supply. The wells are in diameter of $150 \mathrm{~cm}$ and heights between $55-78 \mathrm{~cm}$ from ground surface level. Data on the depth to groundwater level is not available, as some of the wells are sealed. Seawater samples were collected in May 2006. Polyethylene bottles were used to store groundwater samples based on the methods described in APHA (1995). The water $\mathrm{pH}$, temperature, electrical conductivity (EC), salinity and total dissolved solids were measured using WTW $\mathrm{pH} 315 \mathrm{i}$ for $\mathrm{pH}$ and temperature, WTW Cond. 315i for EC and salinity, and TDS using Oaklab 13. Samples were filtered and kept in different polyethylene bottles for analyses of cations and anions. The samples were stored at 1 - 4 ${ }^{\circ} \mathrm{C}$ temperature prior to analysis in the laboratory. Water samples collected were filtered through 0.45 $\mu \mathrm{m}$ membrane filter paper (Millipore ${ }^{\circledR}$ ) using glass filtration unit and acidified with concentrated $\mathrm{HNO}_{3}$ acids.

Table 1: Average concentrations of various elements in the groundwater of Manukan island (Na, Mg, Ca, K, Cl, $\mathrm{SO}_{4}$ and $\mathrm{HCO}_{3}$ in mg/L; Ag, Al, Ba, Fe, Mn, Ni, Se, Zn, Cr in $\mu \mathrm{g} / \mathrm{L}$; Temp. in ${ }^{\circ} \mathrm{C}$, Sal. in ppt and EC in mS/cm)

\begin{tabular}{|c|c|c|c|c|c|c|c|c|c|c|c|c|c|c|}
\hline Point & PK 1 & PK 2 & PK 3 & PK 4 & PK 5 & PK 6 & PK 7 & PK 8 & PK 9 & Mean & SD & $\begin{array}{l}\text { CV } \\
(\%)\end{array}$ & $\begin{array}{l}\text { Seawater } \\
\text { (Mean) }\end{array}$ & $\begin{array}{l}\mathrm{WHO}^{1} \\
(\mathrm{mg} / \mathrm{L})\end{array}$ \\
\hline $\mathrm{pH}$ & 7.0 & 7.5 & 7.1 & 7.1 & 7.0 & 7.3 & 7.3 & 7.2 & 7.3 & 7.2 & 0.17 & 2.36 & 8.1 & NS \\
\hline Temp. & 28.4 & 28.3 & 28.8 & 28.9 & 27.1 & 28.2 & 27.8 & 27.1 & 27.5 & 28.0 & 0.67 & 2.39 & 30.4 & NS \\
\hline EC & 3.0 & 3.8 & 5.2 & 4.4 & 6.3 & 4.6 & 4.6 & 1.0 & 4.2 & 4.1 & 1.48 & 36.10 & 42.9 & NS \\
\hline Sal. & 1.3 & 2.2 & 3.2 & 2.6 & 3.9 & 2.7 & 2.7 & 0.3 & 2.4 & 2.4 & 1.05 & 43.75 & 27.8 & NS \\
\hline $\mathrm{Ag}$ & 2.92 & 3.09 & 2.13 & 2.11 & 4.75 & 1.55 & 2.55 & 1.68 & 1.45 & 2.47 & 1.03 & 41.70 & ND & NS \\
\hline $\mathrm{Al}$ & 17.83 & 8.53 & 7.96 & 8.16 & 9.83 & 6.66 & 7.93 & 9.09 & 37.26 & 12.58 & 9.81 & 77.98 & ND & 0.2 \\
\hline $\mathrm{Ba}$ & 45.59 & 30.95 & 7.53 & 13.00 & 57.63 & 16.28 & 16.11 & 13.69 & 13.06 & 23.76 & 17.27 & 72.69 & $\mathrm{ND}$ & 0.7 \\
\hline $\mathrm{Ca}$ & 232.30 & 326.43 & 232.27 & 213.43 & 256.12 & 231.01 & 249.84 & 66.54 & 107.97 & 212.88 & 78.77 & 37.00 & 421.85 & NL \\
\hline $\mathrm{Cl}$ & 1999.4 & 2282.6 & 2632.5 & 2499.3 & 3015.7 & 2232.6 & 2142.7 & 432.20 & 2515.9 & 2194.9 & 725.83 & 33.07 & $16,347.34$ & 250.00 \\
\hline $\mathrm{Cr}$ & 0.53 & 0.65 & 0.53 & 0.68 & 0.46 & 0.67 & 0.55 & 0.66 & 0.39 & 0.57 & 0.10 & 17.54 & $\mathrm{ND}$ & 0.05 \\
\hline $\mathrm{Fe}$ & 10.49 & 19.88 & 6.10 & 9.54 & 75.45 & 6.60 & 6.92 & 8.77 & 38.02 & 20.20 & 23.10 & 114.36 & ND & 0.30 \\
\hline $\mathrm{HCO}_{3}$ & 401.79 & 374.13 & 273.28 & 293.61 & 305.00 & 295.24 & 319.64 & 394.47 & 285.48 & 326.96 & 49.54 & 15.15 & 90.58 & 250.00 \\
\hline K & 19.04 & 22.68 & 42.43 & 30.70 & 44.34 & 35.68 & 32.08 & 4.55 & 31.44 & 29.20 & 12.32 & 42.19 & 428.65 & NL \\
\hline Mg & 48.70 & 66.25 & 138.55 & 118.79 & 125.15 & 124.95 & 34.56 & 86.34 & 162.46 & 101.64 & 43.63 & 42.93 & 392.53 & NL \\
\hline Mn & 120.70 & 58.93 & 3.26 & 11.34 & 145.83 & 4.86 & 2.77 & 35.31 & 2.54 & 42.84 & 55.01 & 128.41 & $\mathrm{ND}$ & 0.50 \\
\hline $\mathrm{Na}$ & 124.69 & 318.29 & 475.52 & 374.17 & 630.14 & 458.63 & 348.18 & 106.50 & 335.19 & 352.37 & 165.02 & 46.83 & $25,882.36$ & 200.00 \\
\hline $\mathrm{Ni}$ & 2.93 & 0.92 & 0.34 & 0.56 & 0.51 & 0.43 & 0.37 & 0.61 & 0.40 & 0.79 & 0.82 & 103.80 & $\mathrm{ND}$ & 0.02 \\
\hline Se & 394.73 & 701.50 & 1209.0 & 1056.0 & 1740.7 & 1312.7 & 1342.3 & 101.43 & 1098.0 & 995.15 & 510.22 & 51.27 & $\mathrm{ND}$ & 0.01 \\
\hline $\mathrm{SO}_{4}$ & 106.67 & 133.33 & 220.00 & 183.00 & 163.333 & 230.00 & 233.33 & 60.00 & 203.33 & 170.37 & 60.10 & 35.28 & 2200.00 & 250.00 \\
\hline $\mathrm{Zn}$ & 15.52 & 8.79 & 7.22 & 5.12 & 9.17 & 48.97 & 16.93 & 27.39 & 134.47 & 30.40 & 41.35 & 136.02 & ND. & 3.00 \\
\hline
\end{tabular}

SD: standard deviation, CV\% stands for the coefficient of variance. WHO; World Health Organization guidelines, NS: no standards, NL; natural level, ND; no detection.

Table 2: Water types of Manukan island

\begin{tabular}{llllllllll}
\hline & PK 1 & PK 2 & PK 3 & PK 4 & PK 5 & PK 6 & PK 7 & PK 8 & PK 9 \\
\hline March’06 & Na-Cl & Na-Cl & Na-Cl & Na-Cl & Na-Cl & Na-Cl & Na-Cl & Na-Cl & Na-Cl \\
May’06 & Na-Cl & Na-Cl & Na-Cl & Na-Cl & Na-Cl & Na-Cl & Na-Cl & Na-Cl & Na-Cl \\
July'06 & Ca-Cl & Ca-Cl & Na-Cl & Na-Cl & Na-Cl & Na-Cl & Na-Cl & Mg-Cl & Na-Cl \\
\hline
\end{tabular}


Controlling factors of groundwater hydrochemistry in a small island's aquifer

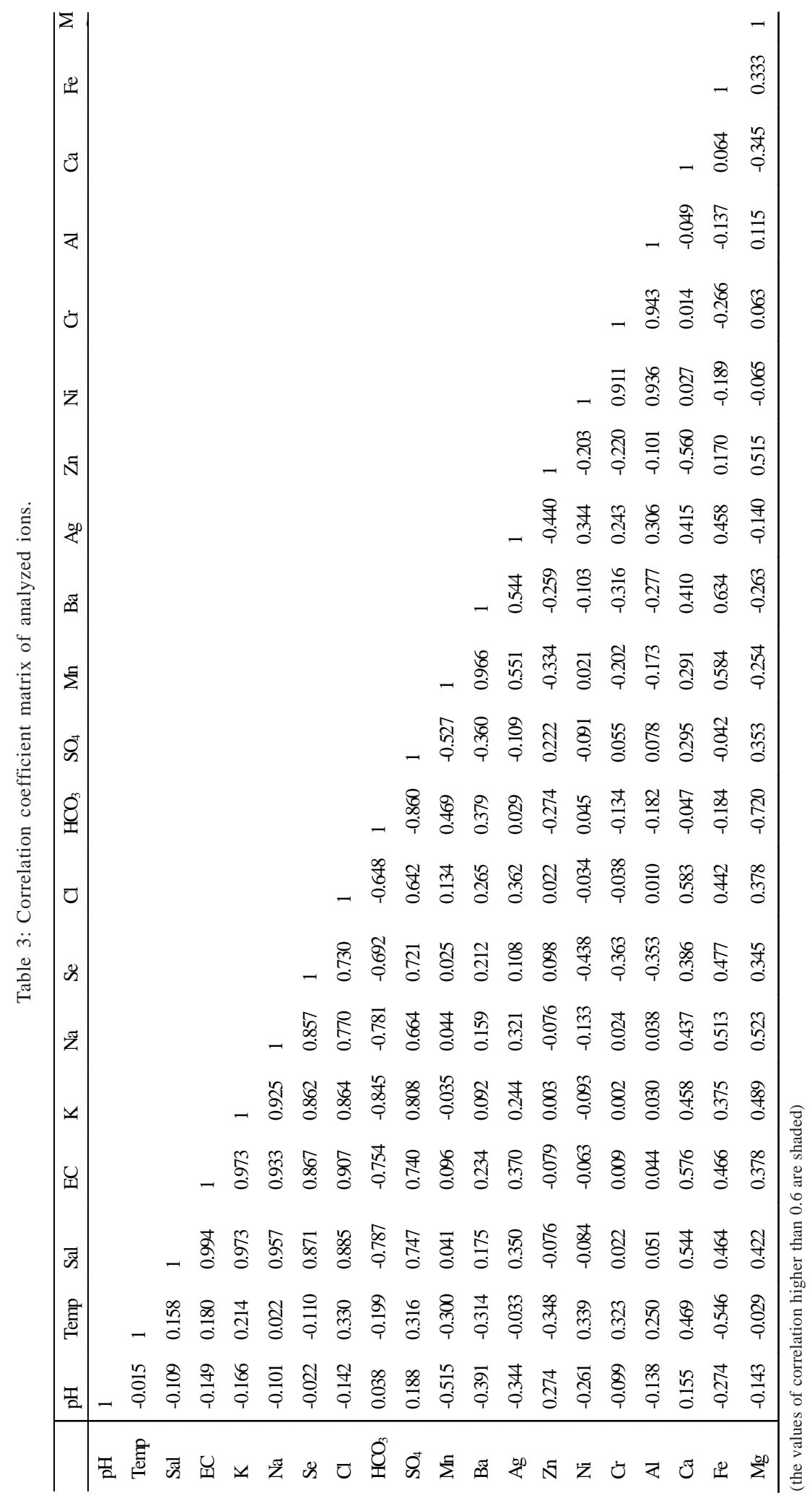




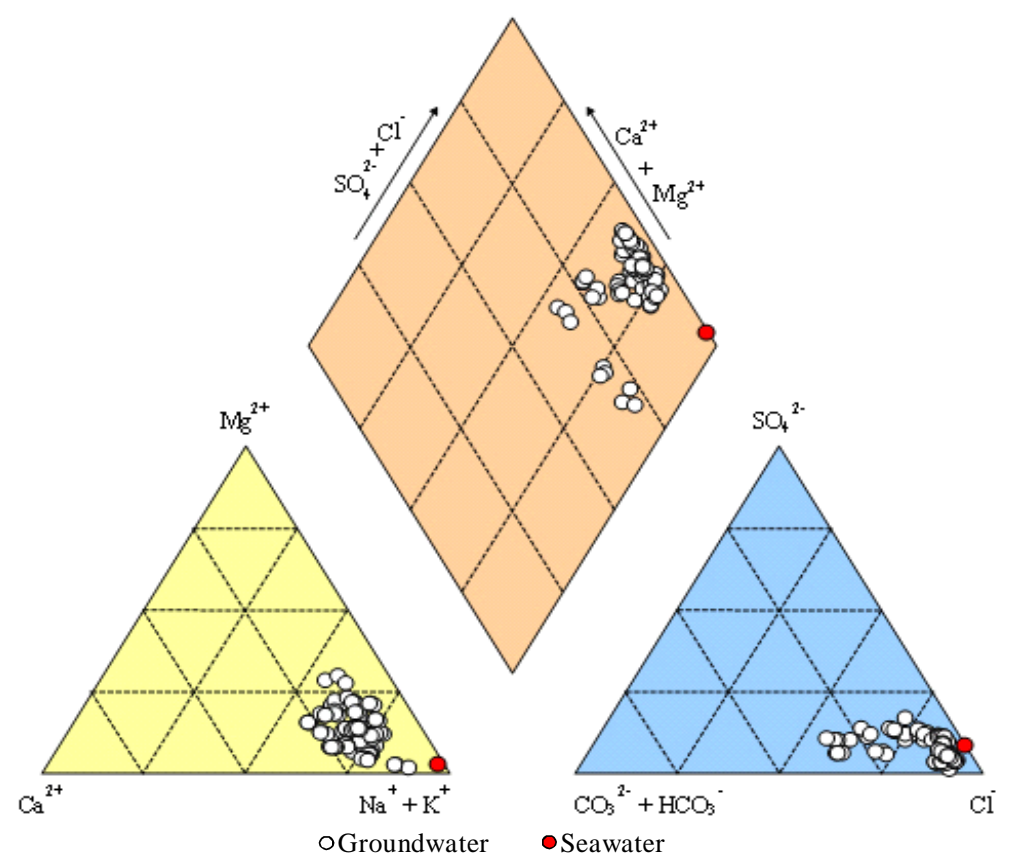

Fig. 2: Piper diagram of the groundwater samples in the study area

Chemical parameters including $\mathrm{Ca}, \mathrm{Mg}, \mathrm{Na}, \mathrm{K}, \mathrm{Cl}$, $\mathrm{HCO}_{3}$ and $\mathrm{SO}_{4}$ were analyzed in the Water Quality Laboratoty of the, School of Science and Technology, University of Malaysia Sabah, Malaysia. The major cations ( $\mathrm{Na}, \mathrm{K}, \mathrm{Mg}$ and $\mathrm{Ca}$ ) were determined using flame (air-acetylene burner) atomic absorption spectrometry (Zeeman Atomic Absorption Spectrophotometer Z-5000, Hitachi, Japan). Sulfate was detected using $\mathrm{HACH}(\mathrm{DR} / 2040)$ meter, $\mathrm{Cl}$ and $\mathrm{HCO}_{3}$ were analyzed using argentometric $\left(\mathrm{AgNO}_{3}\right)$ and titration methods ( $\mathrm{HCl} 0.1 \mathrm{~N}$ ), respectively. Trace elements (Ag, Al, Ba, Fe, Mn, Ni, Se, $\mathrm{Zn}$ and $\mathrm{Cr}$ ) were analyzed by inductively coupled plasma - mass spectrometry (ICP-MS Agilent 7500 ce) at the International Environmental Research Centre, Gwangju Institute of Science and Technology, South Korea.

\section{RESULTS}

The basic properties of groundwater $(\mathrm{pH}$, temperature, electrical conductivity and salinity), major and trace components of the groundwater $(\mathrm{Ca}, \mathrm{Mg}$, $\mathrm{Na}, \mathrm{K}, \mathrm{Cl}, \mathrm{HCO}_{3}, \mathrm{SO}_{4}, \mathrm{Ag}, \mathrm{Al}, \mathrm{Ba}, \mathrm{Fe}, \mathrm{Mn}, \mathrm{Ni}$, Se, Zn and $\mathrm{Cr}$ ) and WHO (2004) guidelines for drinking water are shown in Table 1. The $\mathrm{pH}$ values of groundwater were between 7.0 to 7.5 and no distinct groupings of these values were observed. The salinity of groundwater varied between $0.3 \mathrm{ppt}$ to $3.9 \mathrm{ppt}$.
Table 4: Results of principle component factor analysis with Varimax rotation

\begin{tabular}{lllll}
\hline & F1 & F2 & F3 & F4 \\
\hline Sal & 0.984 & 0.138 & 0.018 & 0.074 \\
$\mathrm{~K}$ & 0.982 & 0.072 & 0.013 & -0.021 \\
$\mathrm{EC}$ & 0.975 & 0.177 & 0.014 & 0.107 \\
$\mathrm{Na}$ & 0.940 & 0.168 & 0.003 & -0.023 \\
$\mathrm{Cl}$ & 0.880 & 0.208 & -0.005 & 0.088 \\
$\mathrm{Se}$ & 0.879 & 0.080 & -0.398 & -0.022 \\
$\mathrm{HCO}_{3}$ & -0.861 & 0.245 & -0.145 & 0.389 \\
$\mathrm{SO}_{4}$ & 0.839 & -0.456 & 0.021 & -0.066 \\
$\mathrm{Mn}$ & -0.107 & 0.920 & -0.134 & 0.293 \\
$\mathrm{Ba}$ & 0.040 & 0.864 & -0.267 & 0.340 \\
$\mathrm{Fe}$ & 0.375 & 0.754 & -0.205 & -0.246 \\
$\mathrm{pH}$ & -0.037 & -0.659 & -0.261 & 0.149 \\
$\mathrm{Ag}$ & 0.239 & 0.647 & 0.340 & 0.375 \\
$\mathrm{Al}$ & 0.037 & -0.034 & 0.974 & -0.043 \\
$\mathrm{Cr}$ & 0.010 & -0.116 & 0.962 & 0.060 \\
$\mathrm{Ni}$ & -0.116 & 0.090 & 0.956 & 0.098 \\
$\mathrm{Ca}$ & 0.488 & 0.076 & -0.042 & 0.820 \\
$\mathrm{Zn}$ & 0.026 & -0.184 & -0.215 & -0.782 \\
$\mathrm{Mg}$ & 0.481 & 0.028 & 0.098 & -0.775 \\
$\mathrm{Variance}$ & $39.80 \%$ & $20.77 \%$ & $17.61 \%$ & $10.07 \%$ \\
\hline & & & &
\end{tabular}


The sampling location with the highest groundwater salinity was PK 5, the nearest well to the shorelines. Pumping of freshwater from the well has been operating for more than 10 years ago. Variations of the electrical conductivity (EC) of the groundwater $(1.0-6.3 \mathrm{mS} / \mathrm{cm})$ were related to the variations of salinity, indicating an influence from seawater intrusion. The groundwater component of Manukan island were dominated by $\mathrm{Na}$ $>\mathrm{Ca}>\mathrm{Mg}>\mathrm{K}$, except stations $\mathrm{PK} 1$ and $\mathrm{PK} 2$ where the dominants ion were $\mathrm{Ca}$; and $\mathrm{Cl}>\mathrm{HCO}_{3}>\mathrm{SO}_{4}$. $\mathrm{Na}$ and $\mathrm{Cl}$ accounts for $40 \%-80 \%$ of the ions. $\mathrm{HCO}_{3}$ accounts around $40 \%$ of the total major ions in any given analysis depending on the well The percentage of ion distributions calculated using the following equation:

$$
\mathrm{X} \%=\frac{\mathrm{Xmg} / \mathrm{L}}{\left(\sum \text { ions }\right) \mathrm{mg} / \mathrm{L}} \times 100
$$

where $\mathrm{X}=$ specific ion ( $\mathrm{Na}, \mathrm{Ca}, \mathrm{Mg}, \mathrm{K}, \mathrm{Cl}, \mathrm{HCO}_{3}$ or $\mathrm{SO}_{4}$ ), and “ ions = total for $\mathrm{Na}, \mathrm{Ca}, \mathrm{Mg}, \mathrm{K}, \mathrm{Cl}, \mathrm{HCO}_{3}$ and $\mathrm{SO}_{4}$. The concentration of analytes in the groundwater collected from different locations showed significant difference where the coefficients of variance of $\mathrm{Fe}, \mathrm{Mn}$, $\mathrm{Ni}, \mathrm{Zn}$ were above $100 \%$. All parameters, except for pH, Temp., EC, $\mathrm{Ca}, \mathrm{Cl}, \mathrm{Cr}, \mathrm{HCO}_{3}$ and $\mathrm{SO}_{4}$, exhibited difference of the coefficients of variance higher than $40 \%$. This implies that geographical location and the environmental conditions (weathering rate and the seawater-freshwater mixing) played an important role in the hydrochemistry characteristics of the groundwater. The concentration of toxic elements, Se at all sampling points was found to be higher than the WHO (2004) standard guidelines for preferable drinking water. Se concentration was between $101-1741 \mu \mathrm{g} / \mathrm{L}$; 10 to 180 times higher than the limit of permissible set by WHO (2004) which is $0.01 \mathrm{mg} / \mathrm{L}$. Na concentration exceeded WHO (2004) standards at all sampling locations, except PK 1. The mean value of $\mathrm{Cl}(2150 \mathrm{mg} /$ L) exceeded the WHO (2004) standards (250 mg/L). This parameter was significantly $(r=0.770, p<0.01)$ correlated with $\mathrm{Na}$. It indicates that the groundwater compositions were influenced by the seawater as also shown by its Na-Cl water type in most of sampling points (Table 2 and Fig. 2).

\section{DISCUSSION AND CONCLUSION}

Factors controlling the chemistry of the groundwater

The data were statistically computed using correlation coefficient in order to indicate the sufficiency of one variable to predict to other (Davis,
1986). From the analysis, three different correlation types can be identified in the aqueous systems, namely: (i) highly competitive relationship between ions with the same charge but different valence number, such as Cl with $\mathrm{SO}_{4}(r=0.642 ; p<0.01)$, (ii) a strong chemical association between ions of opposite charge, but with equal valence number such as $\mathrm{Cl}$ with $\mathrm{K}(r=0.864$; $p<$ 0.01 ) and (iii) a noncompetitive correlation between ions of the same type of charge and equal valence number such as $\mathrm{K}$ with $\mathrm{Na}(r=0.925 ; p<0.01)$. The correlation coefficient matrix between the examined ions, which were calculated using linear regression analysis, as illustrated in Table 3. It was found that the correlation between salinity and/with the major components of seawater $\left(\mathrm{Na}, \mathrm{Cl}\right.$ and $\left.\mathrm{SO}_{4}\right)$ showed significance correlation (Sal-Na, $r=0.957$; Sal-Cl, $r=0.885$; and Sal$\mathrm{SO}_{4}, r=0.747$ with ; $\left.p<0.01\right)$; an indication of seawater influence on the groundwater salinity. The variation of these relationships may indicate the complexity of the hydrochemical components of groundwater where natural water always contains dissolved and suspended substances of mineral origin (Jain et al., 2006). In general, there were two main factors that played an important role in shaping the chemistry and the quality of the water in the aquifer, viz (i) anthropogenic factors: over abstraction of freshwater from the aquifer and (ii) natural factors: mixing between seawater and freshwater at the sharp interface and also carbonate saturation condition.

From the computed data, four factors explaining 88 $\%$ of the variance in the data were obtained and rotated according to the orthogonal varimax method, and their respective loadings are reported in Table 4 . The values of factor loading higher than 0.65 are shaded.

The following factors have been computed for the hydrochemical aspects of the groundwater:

i) Factor 1 (F1): Sal, EC, K, Na, Cl, Se, $\mathrm{SO}_{4}, \mathrm{HCO}_{3}$

ii) Factor 2 (F2): $\mathrm{pH}, \mathrm{Mn}, \mathrm{Ba}, \mathrm{Fe}, \mathrm{Ag}$

iii) Factor $3(\mathrm{F3})$ : $\mathrm{Al}, \mathrm{Cr}, \mathrm{Ni}$

iv) Factor 4 (F4): Ca, Zn, Mg

Factor 1 (F1) accounted for $39.40 \%$ of the total variance and was characterized by the association of Salinity(Sal), EC, $\mathrm{K}, \mathrm{Na}, \mathrm{Cl}$, Se, $\mathrm{SO}_{4}$ and $\mathrm{HCO}_{3}$. There is significant correlation $(r=0.981, p<0.01)$ between the $F 1$ score and the salinity of groundwater for each well an indication to the mixing of seawater in the freshwater system. The variable association was a mark to the role of seawater intrusion into the aquifer. 
Int. J. Environ. Sci. Tech., 4 (4): 441-450, Autumn 2007

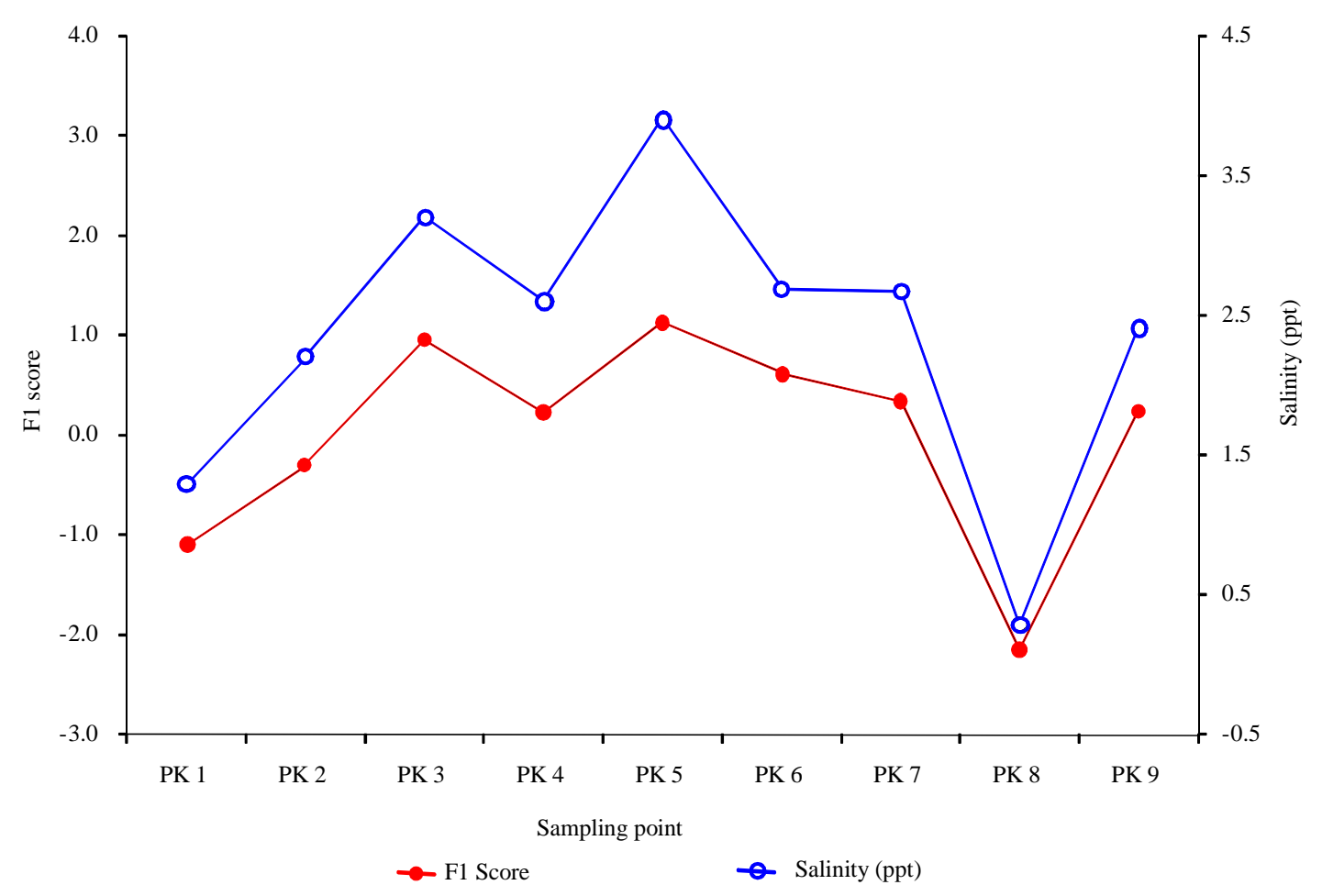

Fig. 3: The relationship between average F1 score and salinity of groundwater

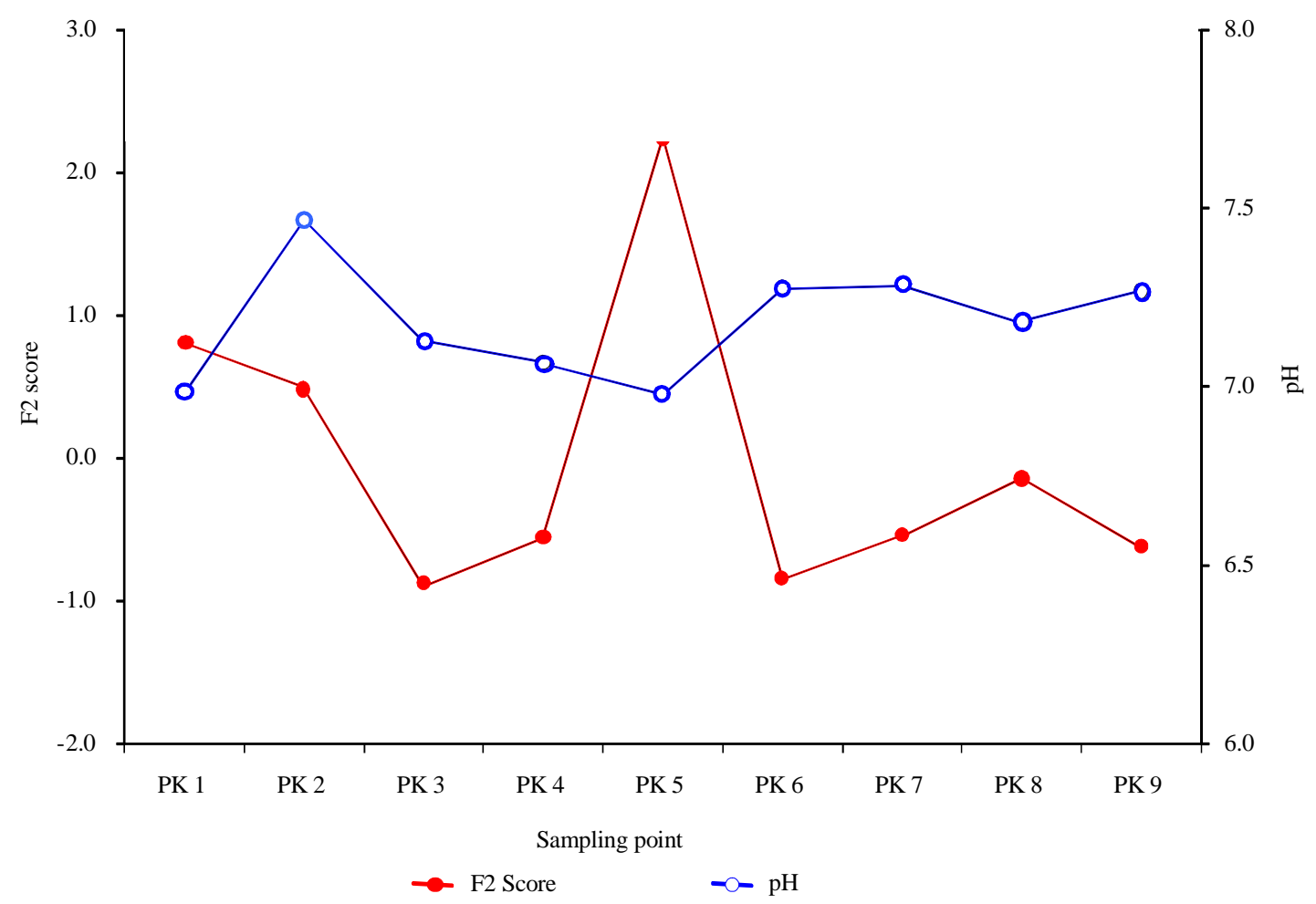

Fig. 4: The relationship between average F2 score and $\mathrm{pH}$ of groundwater 
Sampling point PK 5 exhibits the highest $F 1$ score (Fig. 3). This is due to the closer location of PK 5 to the shoreline compared to the other wells. Compared to PK 3, the F1 score was slightly closer to PK 5 F1 score as PK 3 situation is also quite closer to shorelines indicating that seawater intrusion into the groundwater in this small island. However, F1 scores for PK 6 and PK 7 were slightly lower compared to PK 5 and PK 3. The location of PK 6 and PK 7 are in the centre of the study area and further from the shorelines. This indicates that the seawater intrusion process was also controlled by the upward movement of the seawater into the aquifer attributed by extreme forced from pumping activity.

Basically, the intrusion may be attributed to the over abstraction of groundwater from the aquifer and also from the effect of sea tides (Bear et al., 1999; Abdullah et al., 2002; Aris et al., 2007; Gallardo and Marui, 2007). Precipitation of minerals took place during the cation exchange process which was the later effect from the seawater intrusion into the aquifer. The lower concentration of $\mathrm{Ca}$ compared to $\mathrm{Na}$, was the result from the cation exchange process that occurs naturally when seawater intrudes into the aquifer system. The lower concentration of $\mathrm{Ca}$ compared to $\mathrm{Na}$ is a result from the cation exchange process that occurs naturally when seawater intrudes into the aquifer system. In the carbonate sedimentary system such as in Manukan, with Ca as the dominant ion for the aquifer matrix, the above mentioned process could have occured when seawater intrudes the aquifer:

$$
\mathrm{Na}^{+}+\frac{1}{2} \mathrm{Ca}-\mathrm{X}_{2} \rightarrow \mathrm{Na}-\mathrm{X}+\frac{1}{2} \mathrm{Ca}-\mathrm{X}_{2}
$$

Factor 2 (F2) exhibits high loadings with respect to $\mathrm{pH}, \mathrm{Mn}, \mathrm{Ba}, \mathrm{Fe}$ and Ag, accounting $20.77 \%$ of the total variance. The source of Fe in the groundwater is weathering process of minerals. Under reduction condition, ferric oxides and oxyhydroxides such as hematite $\left(\mathrm{Fe}_{2} \mathrm{O}_{3}\right)$ or goethite $(\mathrm{FeOOH})$ could possibly leached out as dissolved Fe. This is also supported by earlier mineralogical investigations performed by Abdullah, et al. (1997b). The concentrations of Fe and $\mathrm{Mn}$ are quite high due to the effect of $\mathrm{pH}$ to the sorption condition of these cations on the calcite crystal surface (Apello and Postma, 2005). Occurance of Fe and $\mathrm{Mn}$ in groundwaters of near-neutral $\mathrm{pH}$ can generally be at least qualitatively explained by the relationship of F2 score with $\mathrm{pH}$ (Fig. 4). This conditions lead to the enrichment of these dissolved cations in the groundwater. Perhaps, presence of Fe and $\mathrm{Mn}$ in sulfide fraction (especially at coastal zone) might be indicative of initial stages of conversion of oxidation state into reducing one (Karbassi, 1996). Sources of Mn occurrence could be from weathering process where it is an important constituent of some alkaline volcanic rocks and also can be found to be very small in amounts in carbonate solid solutions (Hem, 1989). Beside, intensive weathering of corals depositions and leaching of soil in the aquifer would likely have transferred such trace metals into well water. Nevertheless, $\mathrm{pH}$ in relation to F2 implied that weathering process might have significantly contributed to the enrichment of the trace metals in the groundwater on this small island (Fig. 4). Ba and Ag were found in most land soils at trace levels where the presence of $\mathrm{Ba}$ and $\mathrm{Ag}$ in the groundwater could be the effect from the dissolution and weathering process. Overall, F2 is likely to be controlled by the leaching process that enriches $\mathrm{Mn}, \mathrm{Ba}, \mathrm{Fe}$ and $\mathrm{Ag}$ as correspond to the $\mathrm{pH}$ values. Factor 3 (F3) contributed $17.61 \%$ to the total variance and was characterized by high loadings of $\mathrm{Al}, \mathrm{Cr}$ and $\mathrm{Ni}$. Low levels of $\mathrm{Al}$ and $\mathrm{Ni}$ can end up in soils or water through minerals weathering and mainly varies $(6.66-37.26 \mu \mathrm{g} / \mathrm{L}$ for Al and between $0.34-2.93 \mu \mathrm{g} / \mathrm{L}$ for $\mathrm{Ni}$ ). These variations are mainly due to the difference of distances between wells and catchments area, i.e.; high relief side. Such a fact was supported by the $\mathrm{CV}$ of $\mathrm{Al}$ which was 78 $\%$ and $\mathrm{Ni}$ was $104 \%$, indicating that the distance and pathway of the recharge water to the aquifer was significantly influenced by the weathering process of rocks contains $\mathrm{Al}$ and $\mathrm{Ni}$. Seawater $\mathrm{Cr}$ content varies strongly, and is usually between 0.2 and $0.6 \mu \mathrm{g} / \mathrm{L}$ (Darmayati et al., 1999). The concentration of $\mathrm{Cr}$ found in the groundwater of Manukan island was between $0.39-0.68 \mu \mathrm{g} / \mathrm{L}$, which is slightly higher than the concentration in seawater. This was attributed to the minerals weathering process of soils since it may contain $\mathrm{Cr}$ as reported by Wittman (1979). The source of $\mathrm{Cr}$ in the groundwater is solely controlled by minerals weathering of base rocks all over the sampling locations as supported by the CV of Cr (18\%). Basically, F3 is controlled by the minerals weathering process. Factor 4 (F4) explains $10.07 \%$ of the total variance and associated with $\mathrm{Ca}, \mathrm{Zn}$ and $\mathrm{Mg}$. 
Calcium and $\mathrm{Mg}$ are major anions in water and relatively related to the natural conditions. This factor is related mainly to dissolution processes of carbonate minerals (calcite and aragonite) as indicated by the $\mathrm{CV}$ values for $\mathrm{Ca}$ and $\mathrm{Mg} ; 37 \%$ and $43 \%$, respectively. The occurrence and level of concentration of $\mathrm{Ca}$ and $\mathrm{Mg}$ in the groundwater was controlled by the base rocks of the island. The low $\mathrm{CV}$ for $\mathrm{Ca}$ and $\mathrm{Mg}$ explains that the coral dissolution enhanced $\mathrm{Ca}$ and $\mathrm{Mg}$ concentration in the groundwater.

The occurrence of significant correlation between $\mathrm{Ca}-\mathrm{Cl}(r=0.6)$ indicated an active seawater intrusion (Gimenez and Morell, 1997), and also shown by the presence of $\mathrm{Na}-\mathrm{Cl}$ water type in the study area. It reflected the inverse cation exchange as described in $F 1$ discussion and explained the inverse cation exchange process. The presence of $\mathrm{Zn}$ in the water could be also attributed to the dissolution of carbonate minerals.

In this paper, the preliminary results of the hydrochemistry characteristics of the groundwater on a small island of Manukan, Sabah, Malaysia are reported. The hydrochemistry concept was deduced by the multivariate analysis and factor analysis. The results of factor analysis give an important clue for better understanding on the dynamic and complexity of the groundwater chemical processes. Although the concentrations of heavy metals in the groundwater were low, the multivariate and factor analysis revealed troubling signs of deterioration in island's groundwater quality. The groundwater quality of the island is rather affected by seawater intrusion attributed to over extraction of freshwater from the aquifer. It is crucial to apply aquifer vulnerability mapping with the purpose to protect the groundwater quality from deterioration. The extensively use of groundwater to cater the increasing demand for water supply might create a major problem in the future. The influence of sea tides to the mixing of freshwater-seawater at its interface should be addressed in the future studies. As groundwater is the main freshwater supply for the Manukan island, it is necessary to develop a groundwater management plan for sustainable use of this vital resource. For the proper management plan studies on the island hydrology, the first step should be taken is to study the flow rates of the aquifer in order to develop a numerical groundwater flow model as well as to study the movement of seawater intrusion into the aquifer.

\section{ACKNOWLEDGMENTS}

The authors thank to Ms. Se Young Kim for her assistance with ICP-MS analyses. Special thanks to the International Environment Research CentreGwangju Institute of Science and Technology, South Korea for the technical assistance for this study. An approval from the Sabah Parks Trustees for the study site exploration is highly acknowledged. This study was supported by the Ministry of Science, Technology and Innovation (MOSTI), Malaysia and Universiti Malaysia Sabah. Special thanks also to Ms. S. Mangala Praveena for the assistance during the field sampling.

\section{REFERENCES}

Abdullah, M.H.; Aris, A.Z., (2005). Groundwater Quality of Sipadan Island, Sabah: Revisited - 2004. Proceedings of the 2nd Regional Symposium on Environment and Natural Resources, 254-257.

Abdullah, M.H.; Musta, B., (1999). Phreatic water quality of the turtle islands of East Malaysia: Pulau Selingaan and Pulau Bakkungan Kechil. Borneo Sci., 6, 1-9.

Abdullah, M.H.; Kassim, M.A.; Hanapi, M.N., (2002). Saltwater encroachment into the sandy aquifer of Manukan Island, Sabah. Borneo Sci., 12, 1-22.

Abdullah, M.H.; Mokhtar, M.B.; Tahir, S.; Awaluddin, A., (1997b). Do tides affect water quality in the upper phreatic zone of a small oceanic island, Sipadan Island, Malaysia? Environ. Geo., 29, 112-117.

Abdullah, M.H.; Musta, B.; Tan, M.M., (1997a). A Preliminary Geochemical Study on Manukan Island, Sabah. Borneo Sci., 3: 43-51.

Abdullah, M.H.; Musta, B.; Aris, A.Z.; Annamala, K., (2004) Groundwater Resources of Mabul Island, Semporna, Sabah: Quality Monitoring And Management. Proceedings of the

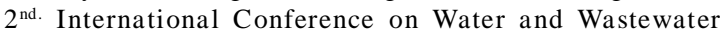
Management and Technologies, 117-120.

APHA, (1995). Standard Methods for the Examination of Water and Wastewater. 19 $9^{\text {th. }}$ Ed. American Water Works Association, Water Environment Federation, Washington. Appelo, C.A.J.; Postma, D., (2005). Geochemistry, Groundwater and Pollution. $2^{\text {nd. }}$ Ed. Balkema, Rotterdam.

Aris, A.Z.; Abdullah, M.H.; Musta, B., (2007). Hydrochemical analysis on groundwater in shallow aquifer of Manukan and Mabul islands, Malaysia. IAHS Red Book (in press).

Basir, J.; Sanudin, T.; Tating, F.F., (1991). Late Eocene planktonic foraminifera from the Crocker Formation, Pun Batu, Sabah. Warta Geo., 14(4), 1-15.

Bear, J.; Cheng, A.H.D.; Sorek, S.; Ouazar, D.; Herrera, I., (1999). Seawater intrusion in coastal aquifers - Concepts, Methods and Practices, Kluwer Academic, Dordretch, The Netherlands.

Darmayati, Y.; Hindarti, D.; Sulistijo., (1999). Asean Marine Water Chemistry for Chromium (Hexvalent). AseanCanada CPMS-II, March, 1999.

Davis, J.C., (1986). Statistics and data analysis in geology $\left(2^{\text {nd. }}\right.$ Ed), John Willey and Sons, New York.

Gallardo, A.H.; Marui, A., (2007). Modeling the dynamics of the freshwater-saltwater interface in response to 
construction activities at a coastal site. Int. J. Environ. Sci. Tech., 4 (3), 285-294.

Gimenez, E.; Morell, I., (1997). Hydrochemical analysis of salinization processes in the coastal aquifer of Oropesa, Castellon, Spain. Environ. Geo., 29, 118-131.

Hem, J.D., (1989). Study and interpretation of the chemical

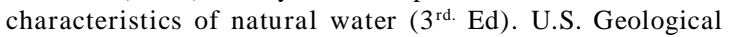
Survey Water-Supply Paper \# 2254, 363.
Karbassi, A. R., (1996). Geochemistry of Ni, Zn, Cu, Pb, $\mathrm{Co}, \mathrm{Cd}, \mathrm{V}, \mathrm{Mn}, \mathrm{Fe}, \mathrm{Al}$ and $\mathrm{Ca}$ in sediments of North Western part of the Persian Gulf. Int. J. Env. Stud., 54, 205-212. WHO, (2004). Guideliness for Drinking-water quality.

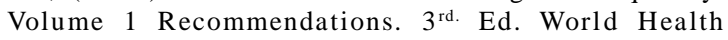
Organization, Geneva.

Wittman, G.T.W., (1979). Metal pollution in the marine environment. Chapter G: Trace metals in water purification processes: 324-360.

\section{AUTHOR (S) BIOSKETCHES}

Aris, A. Z., B.Sc., M.Sc., Department of Environmental Sciences, Faculty of Environmental Studies, Universiti Putra Malaysia, 43400 UPM Serdang, Selangor, Malaysia. Email: zaharin@env.upm.edu.my

Abdullah, M. H., B.Sc., M.Sc., Ph.D., Environmental Science Program, School of Science and Technology, Universiti Malaysia Sabah, 88999 Sabah, Malaysia. Email: harunabd@ums.edu.my

Ahmed, A., B.Sc., M.Sc., Ph.D., Mathematics with Economics Program, Environmental Science Programme, School of Science and Technology, Universiti Malaysia Sabah, 88999 Sabah, Malaysia.

Email:amran@ums.edu.my

Woong, K. K., B.Sc., M.Sc., Ph.D., Department of Environmental Science and Engineering, Gwangju Institute of Science and Technology, Buk-Gu, Gwangju, 500-712 South Korea. Email: kwkim@gist.ac.kr

This article should be referenced as follows:

Aris, A.Z.; Abdullah, M.H.; Ahmed, A.; Woong, K.K.,(2007). Controlling factors of groundwater hydrochemistry in a small island's aquifer. Int. J. Environ. Sci. Tech., 4 (4), 441-450. 